\title{
The Development of Student Worksheets (LKPD) in Learning Science through Group Investigation Learning to Train Critical Thinking Skills of Junior High School Students
}

\author{
Enik Kurniawati \\ Department of Science \\ Universitas Negeri Surabaya \\ Surabaya, Indonesia \\ k_enik@yahoo.co.id
}

\author{
Tjandrakirana \\ Depaertment of Biology \\ Universitas Negeri Surabaya \\ Surabaya, Indonesia \\ nana.snoer@yahoo.com
}

\author{
Sifak Indana \\ Depaertment of Biology \\ Universitas Negeri Surabaya \\ Surabaya, Indonesia \\ sifakindana@unesa.ac.id
}

\begin{abstract}
The purpose of this study is to produce a Student Investigation Worksheet (LKPD) based on Group Investigation learning to train the appropriate Junior High School students'critical thinking skills based on validity, practicality, and effectiveness. LKPD was developed with a 4-D research design namely Define, Design, Develop, and Disseminate. The limited trials were conducted with 30 students. Then, the validity is reviewed from the results of the validation of the RPP and LKPD. The practicality here is reviewed from the implementation of lesson plans (RPP) and the constraints also the activities of students in learning process, and the effectiveness is viewed from the results of the pretest and posttest critical thinking skills and student questionnaire responses. The results of the lesson plans (RPP) category validity are very valid and the reliability is $93 \%$, while the LKPD category validity is very valid and the reliability is $93 \%$. The practicality is reviewed based on the implementation of learning in the excellent category and reliability of $98.8 \%$, the student activity is very enthusiastic. Then, the effectiveness is reviewed from the results of the pretest and posttest which before learning process, none of the students achieved completeness, whereas after 30 trials were declared 22 was completed and 8 incomplete based on the $\mathrm{N}$-Gain calculation the average yield was 0.94 with high criteria. The student responses showed an interest in LKPD of $92.68 \%$ in the very effective category. LKPD that has been developed is valid, practical, and effective. So, it is appropriate to practice the critical thinking skills of junior high school students.
\end{abstract}

Keywords-worksheet (LKPD), group investigation, critical thinking skills

\section{INTRODUCTION}

Nowadays, the education system in Indonesia refers to the 2013 curriculum. Improves and explores the potential of the students in terms of religious competence, social behavior, intellectual, communication competence, caring attitude as social beings, and active to take a role in realizing the life of the nation, state and life to become better is the application of the 2013 curriculum. According to [16] of this 2013 curriculum stated that the teachers also are required to have competence and always be creative in the implementation of learning process, including the learning process of science in the classroom. Based on the results of the PISA (Program for International Student Assessment) 2015 to 69 countries, PISA confirmed Indonesia's students ranked 62 out of 69 participating countries with 403 points in the field of science [10]. In addition, based on the results of the 2018 Junior High Schools' UNBK, the average value of Sciences (IPA) has decreased by 49.18 . It shows that the scientific achievements of Indonesian students in general are still classified as very low compared to other countries. According to [13] stated that there are learning systems which still found that the teacher did not involve the students to be active in the class, the information is often conveyed only in one side or called teachers' centered and there is no interaction between the students in learning. This can occur because teachers rarely to conduct learning in groups. So that, the students become passive and lack of motivation in learning. According to [6] stated that in the process of growing critical thinking skills, students are given the opportunity by the teacher to participate and work together in solving a problem. To be able to solve problems by working together on learning, it is necessary to apply cooperative learning. One of the cooperative learning models that can involve the active role of students is the Group Investigation (GI) model. In the GI Model, the students can be trained to develop their own thinking competencies. The involvement of students from the beginning to the end of the learning process looks active. Therefore, the researchers are interested in conducting research under the title "The Development of Student Worksheets (LKPD) in Learning Science through Group Investigation Learning to Train Critical Thinking Skills of Junior High School Students" (Material Reproductive System in humans).

\section{REVIEW OF RELATED LITERATURE}

\section{A. Group Investigation Learning Model}

The teachers who apply group investigation learning model will arrange their classes and divide them into heterogeneous groups and consist of five to six group of students. But under certain conditions, students can be made into one group based on their friendship or interest in a particular topic. The position of the teacher in the Group Investigation model, as explained that the teacher's role will be a facilitator and provide direction for group activities (helping students formulate learning plans, carry out learning, organize groups) [5]. The teacher also acts as an academic trainer.

According to [14], the investigative group learning model can actually be seen as a "problem solving" learning model or a "discovery" model. But, the group investigation learning model is likely to deal with different problems and the possibility of a spreading problem.

Related to the stages in this group investigation learning model, Sharan (in [7]) explains the six stages in the group investigation model: 
1) Selection of Topics

Students determine their choices in certain sub-topics / themes in a problem described by the teacher. Then, the students join into groups of five to six members.

2) Cooperative Planning (Cooperation)

Students in each group together with the teacher, will plan how to learn and the tasks that students must do.

3) Application

Learners implement the learning plan that has been planned in the second stage. Learners must be involved in various activities and skills and must provide a direction.

4) Analysis and synthesis

Learners make an analysis and evaluation of the information obtained in the third stage and make a plan of investigative activities which can be summarized in various performances or attractive appearance for stage 5 activities for all students in class.

5) Presentation of Final Results

The report of group discussion results is presented attractively by some or all groups based on topics / themes that have been learned through group discussions. So that, all students can be involved in class in other group work.

6) Evaluation.

The teacher together with the students make an evaluation of the participation of each group on the work of the students in the whole class.

\section{B. Critical Thinking}

Critical thinking becomes something which is discussed in all over the world of education [4]. Critical as used in expressions of critical thinking means the importance or centrality of thought that leads to a problem [8]. So, through critical thinking someone will analyze a problem to find a solution or answer to that problem.

Critical thinking skills are reflective thinking abilities and can be accepted by reason focused on the decisions taken about what will be believed or carried out [3]. This skill becomes a thinking ability that is very necessary in making decisions on a problem. Students will be called having the ability to think critically if they are able to gather various information about a problem, then identify the problem and make an evaluative conclusion from the various information [1]. The use of critical thinking competencies will make it easier for someone to evaluate a decent argument based on their thinking [8]. The ability to think critically will train someone to always consider decisions based on the evaluation of arguments. Evaluation of arguments certainly requires knowledge of the problem which being analyzed.

\section{METHODS}

This is a qualitative research. This research is a kind of the development research because it develops science learning LKPD through cooperative learning Group Investigation model to train critical thinking skills of junior high school students (Material Reproductive System in humans). This study uses a four D model (4D) development model [15]. The aim of this study is to train students' critical thinking skills through cooperative learning Group Investigation model of science learning LKPD which is tested to 30 students.
The research procedures are further steps in the study, and this study consists of 2 main steps, namely the development of LKPD and implementation.

In this stage, a GI-based learning device development product was developed to practice critical thinking skills. Learning devices developed include syllabus, lesson plans, LKPD, and learning assessment instruments. This stage consists of three main steps, namely expert review, product validation, and trial I.

The implementation phase is carried out to determine the effectiveness of the LKPD devices in teaching and learning activities in the classroom. In addition, the implementation was also carried out to determine the development of critical thinking skills of class IX students through GI-based LKPD.

This study uses a trial design model of One Group Pretest-Posttest Design, which is carried out in 3 classes as repetition, each class has 10 students.

\section{RESULTS}

\section{A. The Result of Learning Devices}

\section{The Result of Lesson Plans' Validation (RPP)}

The RPP is validated by three experts. The part assessed by the validation expert covers aspects of format, aspects of content and aspects of language suitability. Validation results can be seen in table 1 .

\section{TABLE I. THE VALIDATION RESULT OF LESSON PLAN}

\begin{tabular}{|c|c|c|c|}
\hline No & Rated Aspect & $\begin{array}{c}\text { Average } \\
\text { Validator } \\
\text { Score }\end{array}$ & Category \\
\hline 1 & Format & 4 & Very valid \\
\hline 2 & Learning Activity & 4 & Very valid \\
\hline 3 & Learning Support & 4 & Very valid \\
\hline 4 & Language & 3,6 & Very valid \\
\hline \multicolumn{2}{|c|}{ Reliabilities } & $93 \%$ \\
\hline
\end{tabular}

From Table 1, it is known in general that the results of expert validation of the RPP which the researchers compiled are categorized as very valid so that they can be used with a slight revision and reliability of $93 \%$

\section{1) The LKPD Feasibility Validation Results}

The researchers are developed LKPD by applying the cooperative learning group investigation model. LKPD as a guide for students to carry out group investigation activities in learning activities. This LKPD was prepared by researchers, then assessed by three experts. Validated aspects include format, language and content. LKPD assessment results can be shown in Table 2 . 
TABLE II. . THE LKPD FEASIBILITY VALIDATION RESULTS

\begin{tabular}{|c|c|c|c|}
\hline No & Rated Aspect & $\begin{array}{c}\text { Average } \\
\text { Validator } \\
\text { Score }\end{array}$ & Category \\
\hline 1 & LKPD Format & 3,6 & Very valid \\
\hline 2 & $\begin{array}{c}\text { The Content } \\
\text { Eligibility }\end{array}$ & 4 & Very valid \\
\hline 3 & Language & 3,6 & Very Valid \\
\hline \multicolumn{3}{|c|}{ Reliabilities } & $93 \%$ \\
\hline
\end{tabular}

Table 2 shows that in general, the LKPD assessment results were arranged in very valid categories so that, they could be used with a slight revision and reliability of $93 \%$. However, if viewed from the aspect of language, there is still a little revision or improvement. So that, it can be used in the learning process.

2) The Validation Results of the Critical Thinking Questions.

The Critical thinking skills test questions are prepared by researchers, used to measure students' critical thinking competencies after learning activities on material in the human reproductive system. The type of questions developed are about 4 questions that represent indicators of critical thinking skills, namely providing basic clarification, providing further clarification (advanced clarification), inference, and making estimates. The results of validating the critical thinking skills test questions are presented in Table 3.

TABLE III. THE VALIDATION RESULTS OF THE CRITICAL

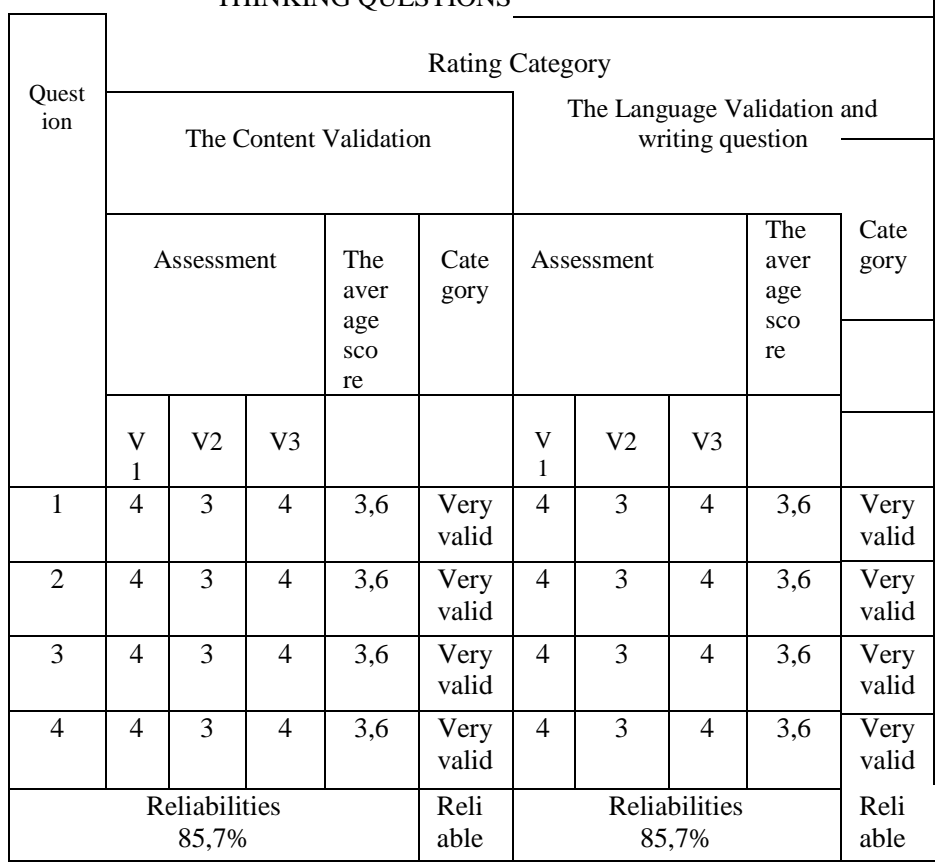

Based on Table 3, it shows that the validation score of the critical thinking skills test which includes content validation with a score of 3.6 (categorized as very valid) and language validity and writing questions with a score of 3.6 (categorized as very valid) on each item with a little revision

\section{B. The Implementation of LKPD Device and Learning}

\section{1) The Result of Lesson Plans (RPP) Implementation}

The score of the implementation of the cooperative group investigation model of each stage in the first and second meetings RPP is shown in Figure 1.

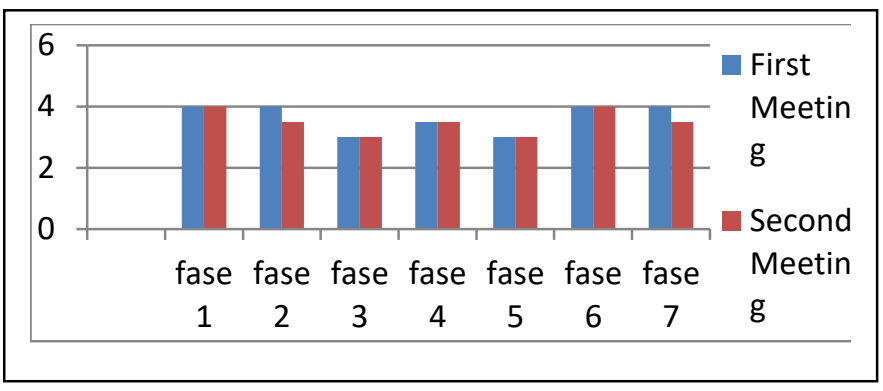

Figure 1. Graphic of the Learning Implementation

\section{2) The Analysis Results of Students' Critical Thinking Assessment after Participating in Learning}

Critical thinking skills tests are given in to two tests namely before and after learning. To find out the results of critical thinking competency assessment before and after treatment can be seen in Figure 2 .

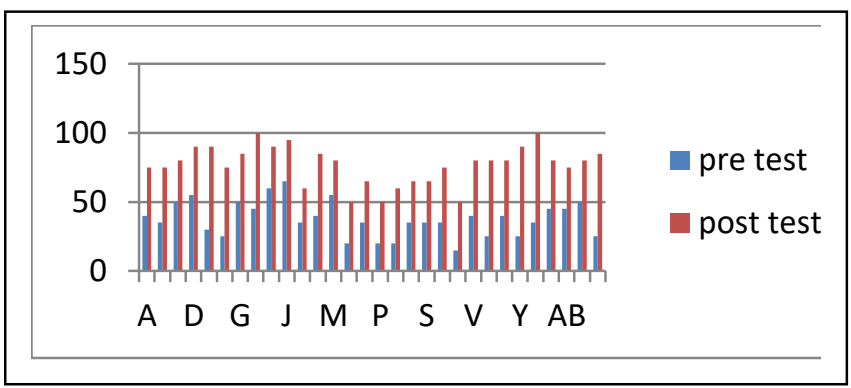

Figure 2. The Graphic of the students' result of pretest and posttest

3) The Analysis Results Students' Responses to Learning Activities.

The students' responses are the opinions of students regarding cooperative learning models of the Group Investigation type. To find out student responses related to learning, students are required to fill out a questionnaire after KBM as in Figure 3. 


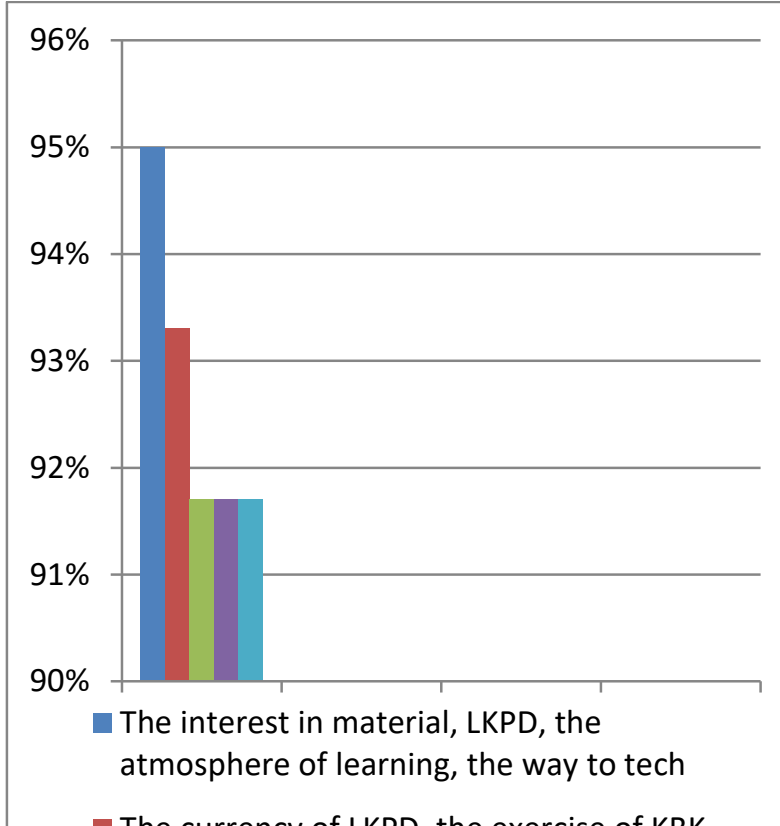

The currency of LKPD, the exercise of KBK

The response to LKPD and the way to teach

- The opinion about the currency of KBK

The students interest

Figure 3. The Graphic of Students' Responses

\section{DISCUSSIONS}

Based on the results and analysis of research data shows that the development of LKPD in learning science-based learning Group Investigation on the material reproductive system in humans can train critical thinking skills of junior high school students and produce devices that have validity, practicality and effectiveness. The valid devices are obtained from assessment devices that are assessed by some validators/experts, while practical devices are obtained from learning achievement sheets, observation sheets of student activity in learning, and effective devices are obtained from tests of critical thinking skills carried out by students and questionnaires for students' responses to LKPD and the model used in learning. Based on the validity of the three validators, stating that the results of the validation of the RPP, LKPD in terms of construct, content and language which were declared highly valid indicate that the RPP, LKPD developed by the researcher was able to answer the learning problem with very valid criteria, the RPP was declared to be suitable for use in Group learning Investigation. This is in accordance with the opinion of Vyrotsky, social relations with other individuals can enhance the construction of new ideas [12]. Practicing critical thinking skills will become easier with group activities through Group Investigation learning.
According to [9], a product development model is said to be practical if the feasibility level of the model has good criteria. Good criteria are obtained from observations of performance. This indicates that the lesson plan learning devices with cooperative group investigation already meet the practical requirements and can be used in learning.

The effectiveness of learning devices can be seen from the results of students' grades in working on the critical thinking skills test instrument that shows an increase in critical thinking skills, this statement is in accordance with the statement of [11] stated that to get knowledge, it takes effort to create a learning process that involves students. In developing the science learning LKPD devices, the GI learning model for students is facilitated to be more active and that requires the right teaching and learning strategies. Based on these opinions and analysis, it can be seen that the science learning model of the group investigation that has been carried out can be declared effective or has an influence on students' critical thinking competencies. So that, it is effective in practicing critical thinking skills of junior high school students. The results of the analysis of student responses can be seen that some students gave positive responses to the learning of Group Investigation to train the critical thinking skills that have been implemented.

\section{CONCLUSION}

From the results of the analysis and discussion of the trial results, it shows that the results of the development of student worksheets (LKPD) on the science learning model of the group investigation learning to train the critical thinking competencies of junior high school students are declared valid, practical and effective and feasible to be implemented.

\section{REFERENCES}

[1] Astuti, Andari Puji. Penerapan Pendekatan Konstruktivisme Berorientasi untuk Meningkatkan Keterampilan Berpikir Kritis dan Hasil Belajar Kimia di SMA Muhammadiyah Plus Salatiga. Jurnal Pendidikan Sains Universitas Muhammadiyah Semarang. 2014, vol 2, no 2, pp 54-62

[2] Dharwadkar, A.A. \&Mohanthy, S. Undergraduate student and faculty perception on small group learning in biochemistry, Int. J. of scie. Rsc edu.. 2015., vol. 3, no 2, pp. 2917-2923.

[3] Ennis, R.H, Critical Thinking. New Jersey: Prentice, 2011.

[4] Fisher, R. Thinking Children to Think. Cheltenham, United Kingdom: Stanley Thornes Ltd., 2012.

[5] Joyce, Bruce and Weil, Marsha. Models of Teaching .Englewood Cliffs, New Jersey: Prentice-Hall, Inc. 2000 
[6] Khaeruddin. Model Pembelajaran Fisika Berbasis Keterampilan Berpikir Kritis. Produk Disertasi Program Pascasarjana Program Studi Pendidikan Sains Universitas Negeri Surabaya, 2013.

[7] Killen, Roy. Effective Teaching Strategies. Australia. Social Science Press. 1998.

[8] Kuswana, W.S., Taksonomi berpikir, Bandung: Remaja Rosdakarya. 2013,

[9] Nieveen, N. Prototyping to Reach Product Quality. Dalam Plomp, T; Nieveen, N; Gustafson, K; Branch, R.M; dan van den Akker, J (eds). Design Approaches and Tools in Education and Training. London: Kluwer Academic Publisher. 1999.

[10] OECD.2015. PISA 2015. Result in focus.

[11] Purniati,T. Penerapan Model Siklus Belajar (Learning Cycle) untuk Meningkatkan Pemahaman Konsep Mahasiswa”. Jurnal Penelitian. Vol. 9 no. 1. April, 2009.
[12] Slavin, Cooperative Learning: Teori, riset dan Praktik. Terjemahan Nurlita. Bandung: Penerbit Nusa Media. 2015.

[13] Sumarli \& Murdani, E.. Model Pembelajaran kolaboratif dengan tutor sebaya pada pokok bahasan rangkaian seri-paralel hambatan listrik. Jurnal Riset dan kajian pendidikan Fisika (JRKPF)UAD. 2015, Vol. 1, No. 2, pp. 42-46.

[14] Soedjadi, R., 1999. Kiat Pendidikan Matematika di Indonesia, Jakarta: Direktorat Jenderal Pendidikan Tinggi Departemen Pendidikam Nasional.

[15] Thiagarajan, S.,D,S., Semmel \& M.I., Semmel. (1974). Instructional Development for Training Teacher of Exceptional Children. Minnepolis Indiana University.

[16] Widi Asih, Wisudawati dan Sulistyowati, Eka. Metodologi Pembelajaran IPA, Jakarta: Bumi Aksara. 2014. 